\title{
Desilylative or Decarboxylative Photoadditions with Graphitic Carbon Nitride
}

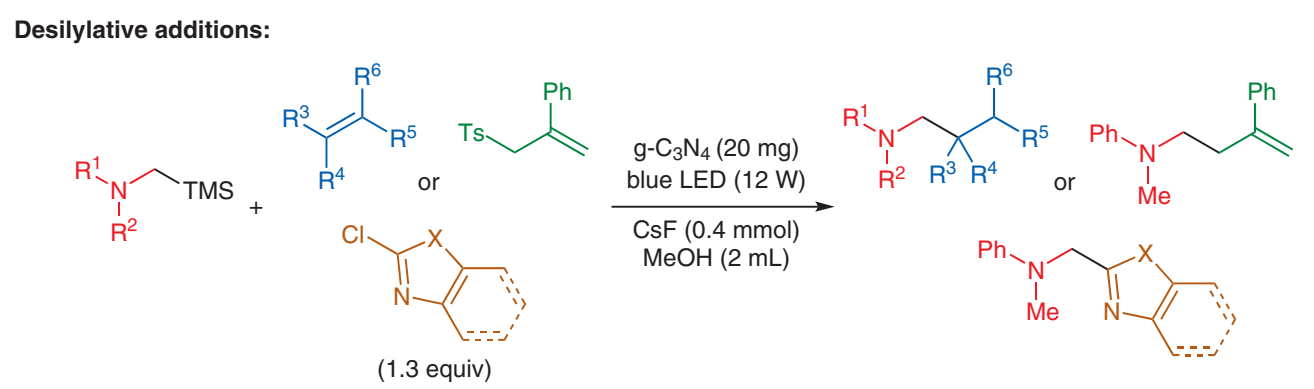

Selected results:<smiles>CN(CC1CCCC(=O)C1)c1ccccc1</smiles><smiles>Cc1ccc(C(CN(c2ccccc2)[N+]([O-])([O-])[O-])C(C#N)C#N)cc1</smiles><smiles>C=C(CCN(c1ccccc1)c1ccccc1)c1ccccc1</smiles>

Decarboxylative additions:<smiles>[R16]NC([R])C(=O)OCC</smiles><smiles>[R]NC([R])C([R7])([R])C([R])[B]</smiles>

Selected results:

$$
\text { (1.3 equiv) }
$$<smiles>O=C1CCCC(CNc2ccccc2)C1</smiles><smiles>O=C1CCCC(CNc2ccc(Cl)cc2)C1</smiles><smiles>O=C1CCC(CNc2ccccc2)C1</smiles><smiles>O=C1CC(CNc2ccccc2)Oc2ccccc21</smiles>

Significance: A graphitic carbon nitride $\left(\mathrm{g}-\mathrm{C}_{3} \mathrm{~N}_{4}\right)$ catalyzed the desilylative addition of $\alpha$-silylamines to alkenes or heteroaryl chlorides under visiblelight irradiation to give the corresponding adducts in up to $96 \%$ yield (eq. 1). $\mathrm{g}-\mathrm{C}_{3} \mathrm{~N}_{4}$ also promoted the decarboxylative additions of $\alpha$-amino acids to alkenes under similar conditions to afford the corresponding products in up to $79 \%$ yield (eq. 2 ).
Comment: In the desilylative addition of $\mathrm{N}$-methyl- $N$-[(trimethylsilyl)methyl]aniline to 4-(2,2-dicyanoethenyl)toluene, $\mathrm{g}-\mathrm{C}_{3} \mathrm{~N}_{4}$ was reused eight times without significant loss of its catalytic activity. $\mathrm{g}-\mathrm{C}_{3} \mathrm{~N}_{4}$ was applied for the continuous-flow reaction of $\mathrm{N}$-methyl- $\mathrm{N}$-[(trimethylsilyl)methyl]aniline with cyclohexanone to afford the desired amine in $85 \%$ yield. 